Article

\title{
Eco-Industrial Parks Development and Integrated Management Challenges: Findings from Italy
}

\author{
Sara Tessitore *, Tiberio Daddi and Fabio Iraldo \\ Istituto di Management, Scuola Superiore di Studi Universitari e di Perfezionamento Sant'Anna, \\ Piazza Martiri della Libertà, 24, 56127 Pisa, Italy; E-Mails: t.daddi@sssup.it (T.D.); \\ f.iraldo@sssup.it (F.I.) \\ * Author to whom correspondence should be addressed; E-Mail: s.tessitore@sssup.it; \\ Tel.: +39-050-883-973; Fax: +39-050-883-839.
}

Academic Editor: Helmut Haberl

Received: 30 April 2015 / Accepted: 21 July 2015 / Published: 24 July 2015

\begin{abstract}
The evolution of Eco Industrial Parks (EIPs) in Italy is a development opportunity for many territories and companies. Starting from the initial experiences in the 1980s, the Eco Industrial Parks model has spread throughout many of the central and northern regions of the country. The key element of Italian Eco Industrial Parks is the management body, an entity provided by national legislation to manage and coordinate companies and to develop more environmentally sustainable production practices. The survey results describe the role and activities of the management bodies concerning the actions implemented, the interaction with the main stakeholders and the resources and investments. The following research introduces an important environmental management experience implemented in Italy.
\end{abstract}

Keywords: Eco-Industrial Park; management; sustainable development; inter-organizational relationships; industrial ecology; Italy

\section{Introduction}

Eco Industrial Parks (EIPs) have spread throughout many countries, where they have different features and key elements. The literature presents case studies especially on industrial symbiosis to reduce the environmental impact. Few papers describe the management and organizational aspects of 
EIPs. This research, instead, is focused on the management topic and on the relationships between companies and the main stakeholder categories operating to increase the sustainability of the EIPs.

The article has different goals; the main ones are:

- introducing the Italian experience in the international scientific literature;

- showing the existence of different approaches to the EIP implementation;

- demonstrating the relevance of EIP management for the relationships among companies and the environmental improvement.

Generally, the aim of this paper is to present the features of Italian EIP management bodies. National legislation summarizes the main activities of the management bodies (environmental services and infrastructure activation), but there are many differences among the various experiences implemented in the Italian EIPs. This research focuses on the "key elements" of Italian EIP management bodies. In recent years, the presence of this "organizational manager" has spread within the international EIPs, but they have different features and roles than the Italian EIP managers. The article describes the EIP management in Italy and the strategy implemented to develop sustainable industrial production. Indeed, the article introduces the key elements characterizing the management bodies and the activities implemented to achieve environmental improvements and to create synergies among the companies operating within the EIPs. This paper also describes the relationships between the EIP management body and the companies operating in the productive area and the interaction with other stakeholders such as public authorities and local communities.

Starting from the literature review, the research identifies a gap in EIP management, Italian EIPs and the inter-organizational relationships (IORs). The scientific literature doesn't include the main Italian experience of EIP. Generally there aren't details on EIP management and about the actions implemented to manage the companies and the environmental impacts.

The article introduces data and technical information about these aspects. The research questions aim at deepening the article objectives and at promoting new management tools in the international EIPs. The research question concerns "the management challenges to be faced by EIPs" and the action to implement for efficient EIP management.

\subsection{The EIP Concept}

Raymond P. COTÉ in 1994 [1] defined the Eco Industrial Park (EIP) concept as an industrial system which conserves natural and economic resources, reduces production material, energy, insurance and treatment costs and liabilities, improves operating efficiency, quality, workers health and public image, and provides opportunities for income generation from the use and sale of waste materials. This concept was developed by many other researchers such as Lowe and Evans in 1995 [2], the Research Triangle Institute and Indigo Development International in 1994, Ayres in 1995 [3], and others. In recent years, the concept of the EIP has been enriched by other elements such as the network of firms [4] and EIP management [5,6]. Generally, the scientific literature presents the experiences of EIPs in terms of environmental results achieved or technologies adopted and do not describe the management solutions employed to coordinate the activities of enterprises and to promote synergies in the EIPs. The existing case studies focus only on industrial symbiosis or on sharing services. Chertow [7] 
defined industrial symbiosis as "part of the emerging field of industrial ecology, which demands resolute attention to the flow of materials and energy through local and regional economies. Industrial symbiosis engages traditionally separate industries in a collective approach to competitive advantage involving the physical exchange of materials, energy, water, and/or by-products. The keys to industrial symbiosis are the collaboration and the synergistic possibilities offered by geographic proximity. Asian EIPs have implemented initiatives inspired by this industrial symbiosis concept. The first Korean EIP was found in Daedok Technovalley (DTV) [8]. The Chinese case studies have tested industrial symbiosis initiatives, such as the experience of Guitang Group (GG), one of China' s largest sugar refineries [9,10]. Many other case studies emerged from the Chinese experience (as Tianjin Economic Development Area [11]).

The State Environmental Protection Administration (SEPA) has encouraged EIP development in China and many Chinese EIPs have implemented industrial symbiosis initiatives, such as the Nanhai project, Baotou project, Huangxing project, Lubei Project and many others [12].

Other experiences of industrial symbiosis emerged between one mostly industrial cluster and the other companies that use similar resources and generate similar products [13-15]. The Kalundborg EIPs are the first example of industrial symbiosis [15], and many others are followed in other countries such as Australia, the Netherlands, etc. [15-22].

This literature analysis especially focused on industrial symbiosis, while this paper introduces the management topic. This paper aims to explore the topic of EIP management and bridging the literature gap identified in these paragraphs.

\subsection{EIP Management and Inter-Organizational Relations}

This paper describes the experience of EIPs in Italy, characterized by the institution of a management body and by a strong relation among companies. The Italian EIP experience can be also included in the research topic concerning "inter-organizational relationships" (IORs). Oliver [23] defined IORs as relatively enduring transactions, flows, and linkages that occur among or between an organization and one or more other organizations in the same environment. Starting from the 1990s, the research on these topics uncovered the main features of IORs, and many of these can be connected with the concept of EIP management and its implementation, especially in Italy. Håkansson and Snehota [24] affirmed that "generalized connectedness of business relationships implies existence of an aggregate structure, a form of organization chosen to qualify as a network". The business network can be defined as two or more connected business relationships, in which each exchange relation is between business firms that are conceptualized as collective actors [25]. Håkansson and Johanson [26] described the inter-organizational network in terms of actors, activities, and resources influencing each other. Networks can also be described in terms of the different bonds between different actors and resources [27]. Ayres [5] suggested that cooperation within EIPs would be facilitated by a coordination mechanism. Indeed, EIP management can be connected with the "strategic networks" concept, defined by Jarillo [28] as "a self-organizing system where leaders have been identified".

The link between the inter-organizational management and the sustainability is the research topic of a study carried out by Fichtner [29]. The paper started from the assumption of WCED (1987) [30], which affirms that inter-organizational cooperation can support the sustainable development and the 
achievement of economic and ecological benefits. The Fichtner study introduced two case studies to demonstrate the cost saving and environmental benefits that can be achieved by inter-company strategies and cooperation of local firms. Starting from the described assumptions, the inter-organizational relationships can be considered an important theory to be connected with EIP management.

The importance of a coordination team in EIPs is cited in many papers [5,6,31]. Other studies focus on the management activities and coordinator role. Mirata [6] defined the EIP's "coordinating body" as a guidance tool that can contribute to park development and recognizes the strategic role of a "coordinating body". In recent research, the role of EIP management has been identified as a sort of "coordination of the tenants" [32].

Some papers analyze relations and interactions with stakeholders such as companies, trade organizations and public authorities, and the socio-economic aspect of EIPs [33]. A study in 2004 compared six case studies in Germany, the USA and the Netherlands [34]. The comparative analysis shows the successfulness of Dutch EIPs. Their success is attributed to two factors: the active participation of companies and the presence of an association of entrepreneurs/employers to inform companies of the potential benefits connected with the creation of the EIP, which also manages the relationships between companies [35]. Fredrik Von Malmborg [36] shows the importance of the role of local authorities in facilitating the development and management of regional industrial ecosystems.

EIP management is described in some papers in which it is called by various names (EIP management, EIP management body, coordinating body and others). In some instances, the management of EIPs is assigned to proactive institutions that were attempting to encourage the formation of links between tenants [35]. In many other case studies, the EIP manager is a public institution or the biggest company of an EIP. Table 1 shows some case studies where EIP management is cited. For each case study, the type of organization that manages the EIP (such as public institutions, companies or others), the country and the information source are specified.

Table 1. Case studies on eco industrial parks (EIP) management.

\begin{tabular}{cccc}
\hline Country & Case Study & Type of EIP Management Organization & Source \\
\hline UK & Humber region industrial symbiosis programme & Public institution \\
UK & West Midlands industrial symbiosis programme & Regional environmental business association & Ref. [6] \\
UK & Mersey Banks industrial symbiosis programme & Private organisation & Ref. [33] \\
\hline Brazil & Santa Cruz EIP & Central management association & Guitang group \\
China & Guigang & Municipality \\
China & Nanhai & Baotou aluminium industry group \\
China & Baotou & Municipality \\
China & Huangxing & Lubei group \\
China & Lubei & Municipality \\
China & Dalian development zone & Municipality \\
China & Tianjin development zone & Fushun mining industry group \\
China & Fuzhou Hi-Tech development zone & Municipality \\
China & Suzhou industrial park & Municipality \\
China & Yantai Development Zone & Municipality \\
China & Weifang & Municipality \\
China & & Ref. [10]
\end{tabular}


Table 1. Cont.

\begin{tabular}{cccc}
\hline Country & Case Study & Type of EIP Management Organization & Source \\
\hline China & Guiyang city & Municipality & \\
China & Liaoning province & Municipality & \\
\hline Wales & Eco Dyfi project & Agency instituted for controlling area & Ref. [35] \\
\hline USA & Denves & Public institution & Ref. [6] \\
\hline
\end{tabular}

The literature on EIPs has only considered the management and the inter-firm relationships in recent years. Few studies have investigated EIP management or described the activities implemented to coordinate needs and relationships emerged from companies operating in EIPs. In many articles, EIP management is cited without providing details on results achieved and strategies adopted.

The literature review reveals few details related to EIP management and to the activities implemented to coordinate the companies and to develop environmental infrastructures and services. In the literature data on the economic, resources for EIP management were not found.

Taken together, the two previous sections and the gap of literature on EIP management, led us to test the following research question:

Q1: What are its features and how does the management body operate to effectively manage an EIP and promote the environmental sustainability among companies?

Q2: Can the management body tasks, and the social and economic resources that have emerged from the relational system, support the environmental improvement of the EIP?

\section{Methods and Sample Descriptions}

The paper responds to these research questions by introducing the results of a survey of 19 Italian EIPs, which answer those questions. The survey results describe the productive areas implementing EIP concepts, the synergies emerged for some stakeholders and the activities implemented by EIP management bodies to reduce environmental impact and to increase the sustainability of production. This methodological approach aims to collect feedback and suggestions from the EIP management bodies in Italy.

The research was carried out through the following steps:

(1) definition of the list of Italian EIP management bodies to be investigated;

(2) questionnaire design;

(3) data collection;

(4) data analysis.

The first phase aimed to identify the organizations that make up the statistic population, namely, the EIP management bodies to interview. We searched the literature and reports on Italian EIPs. This included reviewing a study by the Region of Emilia-Romagna and ERVET, published in 2010, as well as the Guidelines of the Region of Tuscany in which there are case studies and experiences with the EIP approach. In addition to these documents, we selected some EIP management bodies to interview through desk research. 
EIP management bodies of twenty-five industrial areas were identified, each one representing a different EIP.

The second phase of the research focused on the questionnaire design. The questionnaire consists of 27 questions (multiple choice questions and questions with a Likert scale from 1 to 3 where 1 is the positive judgement and 3 is the negative judgement. Then, the questionnaire has been spread and collected by an online survey platform.

The response rate was $76 \%$ of the Italian EIPs selected. In particular, nineteen EIP management bodies (Table 2) filled out the questionnaire describing their activities and features.

Table 2. EIP management body respondents.

\begin{tabular}{|c|c|c|}
\hline$N$. & Name of Coordinating Body & Name Of EIP \\
\hline 1 & Agenzia Per Lo Sviluppo Del Distretto Industriale Del Mobile Livenza (Asdi) & Distretto Del Mobile Livenza \\
\hline 2 & Anonima & Anonima \\
\hline 3 & CONSER Società Cooperativa Consortile Per Azioni & $1^{\circ}$ Macrolotto Industriale Di Prato \\
\hline 4 & Consorzio Ambientale Castello di Lucento & Consorzio Ambientale Castello Di Lucento \\
\hline 5 & Consorzio Attività Produttive Aree E Servizi & EEPA Modena PIP 9 E PIP 10 \\
\hline 6 & Consorzio Per La Zona Di Sviluppo Industriale Ponte Rosso & Zona Industriale Ponte Rosso \\
\hline 7 & Consorzio Per Lo Sviluppo Industriale Del Friuli Centrale (Ziu) & Zona Industriale Udine Sud \\
\hline 8 & Consorzio Promozione \& Sviluppo Le Bocchette & Le Bocchette \\
\hline 9 & Consorzio Zona Industriale Apuana & Area Ex Resine \\
\hline 10 & Consorzio Zona Industriale E Porto Fluviale Di Padova & Zona Industriale Di Padova ZIP \\
\hline 11 & Consorzio Zone Imprenditoriali Provincia Di Ancona & Zipa \\
\hline 12 & Cosint & Cosint \\
\hline 13 & Environment Park Spa & Environment Park \\
\hline 14 & Lucca Innovazione e Tecnologia Srl & Area Industriale Comune Di Lucca \\
\hline 15 & Pianvallico Spa & Pianvallico-Petrona-La Torre (Fi) \\
\hline 16 & S.P.A. Navicelli Di Pisa & Darsena Pisana (Pi) \\
\hline 17 & S.Te.P.Ra: & Area Produttiva Naviglio-Bagnacavallo (RA) \\
\hline 18 & Sipro & EEPA San Giovanni Di Ostellato (FE) \\
\hline 19 & Soprip Spa & Polo Agroalimentare EEPA Filagni \\
\hline
\end{tabular}

The EIPs involved in the survey are located in the Italian regions where regional institutions have adopted measures to promote the diffusion of the EIP approach. The 19 EIP management bodies involved in the study are located mainly in Tuscany (6), Emilia-Romagna (4) and Veneto (3).

The EIP management bodies operate in different EIPs that contain varying numbers of companies. EIPs with less than 50 companies compose $32 \%$ of them and those with 50 to 150 companies make up another 32\%. Thirty-seven percent have more than 150 companies. Nineteen EIP management bodies manage EIPs specialized specifically in manufacturing fields (17) and only two productive areas are characterized by a strong presence of crafts and services. The mechanics field characterizes $26 \%$ of EIPs involved in the survey. Details about the productive sectors of the EIPs involved in the survey are reported in Table 3. 
Table 3. Fields that characterize the EIPs involved in the survey.

\begin{tabular}{ccc}
\hline Main Sectors & Number & Percentage \\
\hline Mechanic & 5 & $26 \%$ \\
Textile & 1 & $5 \%$ \\
Services & 1 & $5 \%$ \\
Mining & 1 & $5 \%$ \\
Furniture & 2 & $11 \%$ \\
ITC & 2 & $11 \%$ \\
Shipping & 1 & $5 \%$ \\
Food & 1 & $5 \%$ \\
Handicraft & 1 & $5 \%$ \\
Others & 4 & $21 \%$ \\
\hline
\end{tabular}

Many EIP management bodies are composed of 5-20 employees. These organizations are composed of one or more public or private subjects. The nineteen EIP management bodies can be classified into three categories based on the legal form adopted for their realization:

- Private organization: one company or a group of companies that coordinates an EIP: six EIPs

- Public organization: one or more public organizations (public institution or chamber of commerce) that coordinates an EIP: 4

- Consortium: an organization composed of multiple entities such as companies, institutions, boards: 9 .

In three case studies, the companies operating in the EIP established a Consortium to manage the productive area with their own resources. Those companies are part of the EIP management body and finance and monitor its activities.

\section{Results and Discussion}

In the framework of eco-managed industrial and business estates, the EIP management body plays a vital role. A pivotal element for an Italian EIP is represented by one sole coordinator that is responsible for the managerial and organizational elements. The EIP management body aims at grouping the needs of settled enterprises and satisfies common requests.

Article 26 of Legislative Decree 112/1998 introduced Ecologically Equipped Productive Areas (EEPAs), based on the international concept of the EIP, to the Italian legal system. The decree establishes that EEPA are coordinated by a "unique management system of infrastructure and services". The EIP management body operates to ensure that EIP companies engage in the pursuit of sustainability. It manages the productive areas that implement actions for environmental improvement and socio-economic development. The EIP management body manages the services and the infrastructure of the area, monitors the environmental performance and promotes internal and external communication between companies and institutions and other stakeholders operating for the EIP.

The public regional institutions promoted the spread of EEPAs and defined the role of the EIP management body as preventing pollution, protecting the health and safety of workers, reducing the pressures on the environment and introducing sustainable solutions with relation to logistics and access to EIP production. The Region of Tuscany, where EIPs are widespread, regulated the development of 
EEPAs and the EIP management body role through two acts, Regulation n. 74/2009 (Regolamento in materia di Aree produttive ecologicamente attrezzate APEA-Regulation on Productive Areas Ecologically Equipped-EEPA) and Regional Decree 1245/2009 (Criteri per la definizione delle prestazioni ambientali delle Aree produttive ecologicamente attrezzate-APEA; Criteria for defining the environmental performance of Areas productive ecologically equipped-EEPA). Regional Regulation n.74 defines the concept of the EIP management body as a tool to achieve environmental sustainability objectives (Article 10) in the productive area and in the Region of Tuscany.

Many other Italian Regions have approved laws or guidelines to implement the EEPA approach, including Piedmont, Emilia-Romagna, Marche and others. The legislation of each region identifies two main mandatory tasks: the activation of the EIP management body and the presence of common services and infrastructures for the companies operating within the EIP.

\subsection{Competences and Roles of EIP Management Bodies}

The survey analyzed the activities carried out by the EIP management body. Ten questions investigated in depth how these organizations operate and the activities that take place in the EIP and in support of the businesses. Generally, Italian EIP management bodies manage the environmental services for the companies (37\%) and the development of the EIP (21\%). Services for the companies include environmental and socio-economic services (such as training) while the promotion of EIPs consists of raising awareness of EIP results through public events and communication initiatives (Table 4).

Table 4. Main activities of EIP management bodies.

\begin{tabular}{ccc}
\hline Main Activities by Management Body & Number & Percentage \\
\hline Dissemination and communication & 4 & $21 \%$ \\
Services for companies & 7 & $37 \%$ \\
Services for companies and management of EIP & 3 & $16 \%$ \\
Promotion of EIP and services for companies & 2 & $11 \%$ \\
All these activities & 3 & $16 \%$ \\
\hline
\end{tabular}

Table 5 shows that one of the main roles of the EIP management body is the consultation with the local stakeholders. The research results confirm that the EIP management body often plays a role in representing the interests of the EIP during the consultations with the stakeholders such as Public Institutions or the local community. Indeed, $21 \%$ declared that the EIP management body always represents the EIP in relations with external subjects. In $18 \%$ of the cases, it implements activities for the "maintenance of the EIP's infrastructure". The research of synergies and industrial symbiosis initiatives is promoted by $17 \%$ of EIP management bodies, demonstrating that the role of this subject is connected mainly with the management of the EIP.

A small percentage of EIP management bodies activate and manage environmental services (5\%). There are also EIP management bodies implementing several functions; nine respondents carry out activities about communication and training to promote the EIP. Other respondents are focused on one of the other activities proposed in the questionnaire. 
Table 5. Abilities and services of EIP management bodies within EIPs.

\begin{tabular}{ccc}
\hline Competences and Services & Number & Percentage \\
\hline Maintenance of the EIP infrastructures & 12 & $18 \%$ \\
Management of environmental services & 3 & $5 \%$ \\
Research and innovation & 8 & $12 \%$ \\
Training and awareness & 9 & $14 \%$ \\
Consultation and communication & 9 & $14 \%$ \\
Consultation with local stakeholders (public and private) & 14 & $21 \%$ \\
Search of synergies among the businesses & 11 & $17 \%$ \\
and promotion of industrial symbiosis & & \\
\hline
\end{tabular}

By analyzing in detail the services performed by the EIP management body to support businesses, it emerges that seven manage environmental services such as waste collection, six manage environmental and administrative services and four are also responsible for the organization of socio-economic activities and services such as training activities, public events, marketing initiatives and others. Seventy-four percent of the respondents declared monitoring the environmental performance of the EIP. The monitoring actions take place no more than twice a year for the seven EIPs while six implement two to five initiatives every year. The environmental monitoring of the EIP consists in the analysis of environmental pressures and in periodic data collection on the level of pollution emitted by the companies of the EIP.

The internal and external communication of the EIP is another main ability of the EIP management body. Seventy percent of the respondents declared promoting and raising awareness of the EIP during public events and marketing initiatives. Five EIP management bodies participate in national and international meetings to introduce the performance of their respective EIP and many others are involved in communication activities at the local and regional level.

\subsection{Stakeholder Relations and Synergies}

The survey investigates in depth the relationships between:

- $\quad$ the EIP management body and companies operating within the EIP

- $\quad$ the EIP management body and other stakeholders, particularly Public Institutions

Tudor et al. [37], in a literature review published in 2007, found measures to enhance the success of the EIP such as cooperation (between firms and between firms and local government) on the basis of improving environmental and business performance [20], and the active participation of a range of stakeholders including those of the public sector, representatives from local companies, labour, community and environmental organizations, as well as experts in various fields such as architecture, engineering, ecology and environmental management [20].The relationship between the local stakeholders and the EIP is an important factor in the development and improvement of the EIP, especially in Italy. The survey results confirm this.

As mentioned above, the relationship between the EIP management body and the companies is a key element of EIP development. The first question on this topic aimed to record the existence of an official agreement, i.e., a document identifying the functions conferred by the enterprises to the EIP 
management body. Among the 19 management bodies interviewed, eight confirmed the presence of an explicit agreement. An unofficial agreement exists in seven other EIPs. Unofficial agreement is different from other types of agreements and recognizes some abilities of the EIP management body in a generic way.

The main activities and capabilities assigned to the EIP management body by the official agreement are the management of infrastructures and the communication and consultation with the stakeholders (63\%). Some EIP management bodies conduct research activities related to innovative tools and scale economies for the EIP's companies (38\%).

The questionnaire investigated the level of involvement of enterprises in the EIP "approach" and in the environmental initiatives adopted. Eight EIP management bodies (44\%) declared that the level of involvement is less than $20 \%$ of the EIP's companies, while in six case studies, the implementation of the EIP approach involved over $70 \%$ of companies. In the other EIPs, the involvement of the businesses ranged from $20 \%-50 \%$ to $50 \%-70 \%$.

The relation with the local stakeholders and especially with the Public Institutions is relevant for each EIP management body involved in the survey. The interaction with the stakeholders varies from one EIP management body to another. The level of interaction with the local stakeholders was investigated through three questions aimed at describing the support from stakeholders in the development of the EIP, the interest in the management of EIPs and the activities in which the EIP management body and the local stakeholders cooperate.

The relation between the EIP management bodies and the stakeholders was assessed through three levels of interaction:

- Stakeholders are members of the EIP management body and the support and finance all activities and projects implemented in the EIP. They are part of the organization, established as part of the EIP management body (we assigned a value of +++ ).

- Stakeholders finance the EIP management body and the EIP development (we assigned a value of ++ ).

- Stakeholders interact with the EIP management body for administrative tasks and consultation processes (we assigned a value of + ).

Table 6 shows the assessment of the relation for each EIP management body and the main stakeholder categories. The data collected show that the Municipality is the stakeholder with which the interaction is the greatest. In twelve case studies, the Municipality is a member of the EIP management body and supports its development. The same assessment holds true for the Province and Chamber of Commerce, while the Regional authority especially financed the EIP development and the EIP management body initiatives. The interaction with the trade organization generally concerns the consultation process. 
Table 6. Stakeholders relations.

\begin{tabular}{|c|c|c|c|c|c|}
\hline \multirow[b]{2}{*}{ EIP Management Body } & \multicolumn{5}{|c|}{ Stakeholders } \\
\hline & Municipality & Province & Region & $\begin{array}{l}\text { Chamber of } \\
\text { Commerce }\end{array}$ & $\begin{array}{c}\text { Trade } \\
\text { Organization }\end{array}$ \\
\hline ASDI & +++ & +++ & ++ & +++ & \\
\hline Not specified & +++ & ++ & ++ & & \\
\hline CONSER & ++ & & ++ & & \\
\hline $\begin{array}{l}\text { Consorzio Ambientale } \\
\text { Castello di Lucento }\end{array}$ & ++ & + & + & + & + \\
\hline $\begin{array}{l}\text { Consorzio Attività Produttive Aree e } \\
\text { Servizi APEA MODENA }\end{array}$ & +++ & ++ & ++ & & \\
\hline $\begin{array}{l}\text { Consorzio per la Zona di Sviluppo } \\
\text { Industriale Ponte Rosso }\end{array}$ & ++ & & ++ & & + \\
\hline $\begin{array}{l}\text { Consorzio per lo Sviluppo Industriale } \\
\text { del Friuli Centrale (Ziu) }\end{array}$ & +++ & +++ & ++ & +++ & + \\
\hline $\begin{array}{l}\text { Consorzio Promozione \& } \\
\text { Sviluppo Le Bocchette }\end{array}$ & ++ & & ++ & & + \\
\hline Consorzio Zona Industriale Apuana & +++ & +++ & + & +++ & + \\
\hline $\begin{array}{l}\text { Consorzio Zona Industriale e Porto } \\
\text { Fluviale di Padova }\end{array}$ & +++ & +++ & ++ & & \\
\hline $\begin{array}{l}\text { Consorzio Zone Imprenditoriali } \\
\text { Provincia di Ancona }\end{array}$ & ++ & & ++ & & + \\
\hline Cosint & +++ & +++ & ++ & +++ & + \\
\hline Environment Park & +++ & +++ & +++ & +++ & \\
\hline Lucca Innovazione e Tecnologia & + & + & ++ & +++ & + \\
\hline Pianvallico Spa & & & & & \\
\hline S.P.A. Navicelli & +++ & +++ & ++ & +++ & \\
\hline S.Te.P.Ra: & +++ & +++ & ++ & +++ & + \\
\hline Sipro & +++ & +++ & + & +++ & + \\
\hline
\end{tabular}

\subsection{Economic Resources and Eco-Innovation}

The economic sustainability of the EIP management body is one of the most important aspects to be evaluated. The EIP management body needs funding to carry out the management and development of the productive area. The EIP management body can offer services and support to the companies through resources from various sources such as public funds, contributions from businesses, sponsors and others. It is important that the role of the EIP management body does not become a significant cost for the EIP companies, and so it must also look for resources outside the EIP.

The survey investigated the main funding sources (Table 7) that support the EIP management body. The data collected show that the public funding and contributions from enterprises represent the main source of support for the respondents ( $44 \%$ as cited in the following table). Few EIP management bodies are able to obtain additional funds from sponsors, while the revenues from the management of services represent a significant income source. Seventy percent of respondents declared investing 
resources mainly in the infrastructure for environmental management and in projects to increase the competitiveness of the EIP's companies.

Table 7. What are the main sources of funding and support?

\begin{tabular}{cccc}
\hline Sources & Not Relevant & Relevant & Very Relevant \\
\hline Public founding & $38 \%$ & $19 \%$ & $44 \%$ \\
Financing by enterprises operating in the EIP & $38 \%$ & $31 \%$ & $31 \%$ \\
Sponsors & $69 \%$ & $31 \%$ & 0 \\
Revenues from the services management & $50 \%$ & $21 \%$ & $29 \%$ \\
Revenues from other activities & $69 \%$ & $8 \%$ & $23 \%$ \\
\hline
\end{tabular}

Eco-Innovation is defined as the innovation of a product, process or organizational structure of a company, which leads to a better environment. The European Commission has always invested and promoted Eco-Innovation through its Eco-AP programme, an instrument to identify and implement measures for the introduction of new environmental technologies to improve coordination and cooperation among the European Member States. The EIP management body plays a crucial role in the introduction of eco-innovation solutions in the EIP. Table 8 describes the main investments in eco-innovation: $27 \%$ of EIP management bodies consider investments to improve the waste management very relevant and $18 \%$ promote eco-innovation particularly in the management of raw materials. Sixty percent of respondents assess eco-innovation for the improvement of local stakeholder relations as relevant. The survey also investigated the environmental aspects that the eco-innovation efforts focused on:

- Energy saving: $73 \%$ of respondents;

- Water discharge: $43 \%$ of respondents;

- Waste management: $25 \%$ of respondents.

Table 8. Main investments in Eco-Innovation.

\begin{tabular}{cccc}
\hline Investments & Not Relevant & Relevant & Very Relevant \\
\hline Environmental infrastructure & $13 \%$ & $19 \%$ & $69 \%$ \\
Environmental services & $31 \%$ & $19 \%$ & $50 \%$ \\
Other services & $33 \%$ & $33 \%$ & $33 \%$ \\
R\&D & $20 \%$ & $40 \%$ & $40 \%$ \\
New technologies for sustainable production & $44 \%$ & $31 \%$ & $25 \%$ \\
Projects to increase the company competitiveness & $20 \%$ & $20 \%$ & $60 \%$ \\
\hline
\end{tabular}

\subsection{Environmental Results}

The last question investigated the environmental improvement. EIP management supported the environmental improvement. Respondents identified the environmental aspects which achieved major improvements. Seventy-three percent declared high improvement concerning the energy and $46 \%$ in water discharge. Improvements were registered also concerning the raw material $(49 \%)$ and waste management (42\%) (Table 9). 
Table 9. Main environmental improvement.

\begin{tabular}{cccc}
\hline Environmental Topic & low Improvement & Improvement & High Improvement \\
\hline Energy & $9 \%$ & $18 \%$ & $73 \%$ \\
Water discharges & $38 \%$ & $15 \%$ & $46 \%$ \\
Waste management & $33 \%$ & $42 \%$ & $25 \%$ \\
Water consumption & $50 \%$ & $33 \%$ & $17 \%$ \\
Soil pollution & $50 \%$ & $33 \%$ & $17 \%$ \\
Raw material consumption & $19 \%$ & $69 \%$ & $13 \%$ \\
Air pollution & $71 \%$ & $21 \%$ & $7 \%$ \\
\hline
\end{tabular}

The environmental improvement declared by the coordinating body is supported by few details. There aren't data on the achieved result, especially concerning the environmental topics. The EIPs' management is a recent experience and few coordinating bodies measured and assessed the results achieved. In many case studies, the best practice were started from one or two year and are in progress.

The authors interviewed (by phone) two of the oldest Italian EIPs to investigate the achieved results.

Ponterosso is the coordinating body in an industrial park of Friuli Venezia Giulia. It realized a natural gas plant composed of $c a$. 15,000 $\mathrm{m}$ of pipeline. The EIP companies have begun to increase the use of this infrastructure to transfer their products and there was a $41 \%$ increase of transport by train from 2011 to 2012. The EIP includes a wastewater treatment plant, completed in 2010. The plant has power of around a 7500 population equivalent, and it allows the purifation of the water discharge input from businesses using the best techniques available. The treatment process is monitored by innovative systems that guarantee the compliance of the wastewater with the emission limit values. The Consortium realized a phytoremediation plant of three hectares to further treat the wastewater before putting them in the river near the EIP [38].

Conser is the coordinating body of the Macrolotto of Prato textile EIP. Conser has implemented a mobility management plan since 2012. Conser bought several electric and natural gas vehicles. The companies can use the vehicles to transport goods and persons. Conser monitored the results achieved in a year, highlighting the following environmental benefits thanks to about $104,500 \mathrm{~km}$ of private transport spared: 18 ton-equivalent of $\mathrm{CO}_{2}$ saved, $4 \mathrm{~kg}$ of PM10 spared.

\section{Conclusions}

The evolution of EIPs in Italy is an opportunity to develop for many territories and companies. EIPs can particularly support small and medium companies in their environmental performance improvement and to reduce their commitment to manage the impact, also from an economic perspective. Starting from the initial experiences in the 1980s, the EIP model has spread throughout Italy's central and northern regions. Italian EIPs are continually developing and increasing. The research describes the management of the EIP, which is different from many other case studies in the international literature. Other studies introduce details on the services and infrastructures implemented in EIPs to test the industrial symbiosis model. Our study, instead, introduces the Italian experience and the key elements of EIP management to the literature. The main results can be summarized in some points: 
- The essential characteristic of the Italian EIP is the synergy between companies, sharing resources, knowledge and experience.

- The management body represents a link between the companies and the local stakeholders, especially public authorities.

- The local community participates in the development of the EIP through the management body's identification of needs and requests

- The Italian management body promotes the development of the EIP and the environmental protection.

The research confirms the assumption of many other studies as by Cherow or Mirata but describes in depth the features and activities of Italian EIP management. The relevance of stakeholders' relations emerges as a key element for the EIP development, while in many other studies on EIPs, this aspect is not considered.

The management body's main barrier to development is the difficulty in obtaining the support of businesses, especially in the start-up phase. Another important issue concerns the resources needed to maintain the management body, which is economically supported by the companies and public authorities.

This research does not introduce much data on the results achieved by the EIP management body at the environmental level. Only few interviewed subjects have data and information on environmental improvement. The institution of the EIP management body is quite recent and it is only beginning to activate tools and methods for monitoring environmental performance. The lack of results achieved by the EIP management bodies is the main limitation of this study but could be an opportunity for future research.

\section{Author Contributions}

Sara Tessitore collected data and technical information about the Italian EIPs. She managed the survey. Tiberio Daddi defined the research questions, processed the data and assesses the paper quality. He knows the Italian EIPs very well and defined the main case studies to interview. Fabio Iraldo checks the paper quality and revised the article to guarantee the completeness and comprehensiveness of the information.

\section{Conflicts of Interest}

The authors declare no conflict of interest.

\section{References}

1. Côté, R.P.; Ellison, R.; Hall, J.G.; Klynstra, P.; Martin, M.; Wade, P. Designing and Operating Industrial Parks as Ecosystems; Technical Report, School for Resource and Environmental Studies; Dalhousie University: Halifax, NS, Canada, 1994.

2. Lowe, E.A.; Evans, L.K. Industrial ecology and industrial ecosystems. J. Clean. Prod. 1995, 3, 47-53.

3. Ayres, R.U. Creating industrial ecosystems: A viable management strategy. Int. J. Technol. Manag. 1996, 1, 608-624.

4. Gibbs, D. Trust and Networking in Inter-firm Relations: The Case of Eco-industrial Development. Local Econ. 2003, 18, 222-236. 
5. Ayres, R.U. The Greening of Industrial Ecosystems. In Industrial Metabolism: Theory and Policy; Richards, D.J., Allenby, B.R., Frosch, R.A., Eds.; National Academy of Science: Washington, DC, USA, 1995.

6. Mirata, M. Experiences from early stages of a national industrial symbiosis programme in the UK: Determinants and coordination challenges. J. Clean. Prod. 2004, 12, 967-983.

7. Chertow, M.R. Industrial symbiosis: Literature and taxonomy. Annu. Rev. Energy Environ. 2000, 25, 313-337.

8. Deog-Seong, O.; Kyung-Bae, K.; Sook-Young, J. Eco-Industrial Park Design: A Daedeok Technovalley case study. Habitat Int. 2005, 29, 269-284.

9. Geng, Y.; Doberstein, B. Developing the circular economy in China: Challenges and opportunities for achieving leapfrog development. Int. J. Sustain. Dev. World Ecol. 2008, 3, 231-239.

10. Zhu, Q.; Lowe, E.A.; Wei, Y.; Barnes, D. Industrial Symbiosis in China: A Case Study of the Guitang Group. J. Ind. Ecol. 2007, 11, 31-42.

11. Geng, Y.; Yi, J. Integrated water resource management at the industrial park level: A case of the Tianjin Economic Development Area. Int. J. Sustain. Dev. World Ecol. 2006, 13, 37-50.

12. Fang, Y.; Côté, R.P.; Qin, R. Industrial sustainability in China: Practice and prospects for eco-industrial development. J. Environ. Manag. 2007, 83, 315-328.

13. Chertow, M.R. Experiences and Case Studies. In Industrial Ecology in a Developing Context. Sustainable Development and Environmental Management; Springer Netherlands: Heidelberg, Germany, 2008; pp. 335-349.

14. Ashton, W.S. Social network analysis and industrial symbiosis: Application of a social science tool to understanding industrial ecosystem organization. J. Ind. Ecol. 2008, 12, 34-51.

15. Jacobsen, N. Industrial symbiosis in the making: Bridging social and technical explanations-The case of Kalundborg, Denmark. In Proceedings of the 11th Annual International Sustainable Development Research Conference, Helsinki, Finland, 6-8 June 2005.

16. Chertow, M.R.; Ashton, W.S.; Espinosa, J.C. Industrial Symbiosis in Puerto Rico: Environmentally Related Agglomeration Economies. Reg. Stud. 2008, 42, 1299-1312.

17. Park, H.S.; Renea, E.R.; Choia, S.M.; Chiub, A.S.F. Strategies for sustainable development of industrial park in Ulsan, South Korea-From spontaneous evolution to systematic expansion of industrial symbiosis. J. Environ. Manag. 2008, 87, 1-13.

18. Roberts, B.H. The application of industrial ecology principles and planning guidelines for the development of eco-industrial parks: An Australian case study. J. Clean. Prod. 2004, 12, 997-1010.

19. Eilering, J.A.M.; Vermeulen, W.J.V. Eco-industrial parks: Toward industrial symbiosis and utility sharing in practice. Ind. Ecol. 2004, 1, 245-270.

20. Heeres, R.R.; Vermeulen, W.J.V.; de Walle, F.B. Eco-industrial park initiatives in the USA and the Netherlands: First lessons. J. Clean. Prod. 2004, 12, 985-995.

21. Ehrenfeld, J.; Gertler, N. Industrial Ecology in Practice: The Evolution of Interdependence at Kalundborg. J. Clean. Prod. 1997, 1, 67-79.

22. Korhonen, J.; Snäkin, J. Analysis the evolution of industrial ecosystem: Concepts and application. Ecol. Econ. 2005, 52, 169-186.

23. Oliver, C. Determinants of Interorganizational Relationships: Integration and Future Directions. Acad. Manag. Rev. 1990, 15, 241-265. 
24. Hakansson, H.; Snehota, I. Developing Relationships in Business Networks; International Thomson Press: Boston, MA, USA, 1995.

25. Emerson, R.M. Exchange Theory, Part I: Exchange Relations and Network Structures. In Sociological Theories in Progress; Zelditch, M., Anderson, B., Eds.; Houghton Mifflin: Boston, MA, USA, 1972; Volume 2.

26. Hakansson, H.; Johanson, J. A model of industrial networks. In Industrial Networks: A New View of Reality; Axelsson, B., Easton, G., Eds.; Routledge: London, UK, 1992; pp. 32-46.

27. Mattsson, L.G. An application of a network approach to marketing: Defending and changing market positions. In Changing the Course of Marketing: Alternative Paradigms for Widening Marketing Theory; Dholakia, N., Arndt, J., Eds.; JAI Press: Greenwich, CT, USA, 1984; pp. 263-288.

28. Jarillo, J.C. On strategic networks. Strateg. Manag. J. 1988, 9, 31-41.

29. Fichtner, W.; Tietze-Stöckinger, I.; Frank, M.; Rentz, O. Barriers of interorganisational environmental management: Two case studies on industrial symbiosis. Environ. Sustain. Dev. 2005, 2, 73-88.

30. World Commission on Environment and Development. UN Documents Report of the World Commission on Environment and Development: Our Common Future, Oxford University Press: Oxford, UK, 1987; pp. 173-196.

31. Côté, R.P.; Smolenaars, T. Supporting pillars for industrial ecosystems. J. Clean. Prod. 1997, 5, $67-74$.

32. Burstrom, F.; Korhonen, J. Municipalities and industrial ecology: Reconsidering municipal environmental management. J. Sustain. Dev. 2001, 9, 36-46.

33. Bechara, L.; Veiga, E.; Magrini, A. Eco-industrial park development in Rio de Janeiro, Brazil: A tool for sustainable development. J. Clean. Prod. 2009, 17, 653-661.

34. Gibbs, D.; Deutz, P. Reflections on implementing industrial ecology through eco-industrial park development. J. Clean. Prod. 2007, 15, 1683-1695.

35. Hewes, A.K.; Lyons, D.I. The Humanistic Side of Eco-Industrial Parks: Champions and the Role of Trust. Reg. Stud. 2008, 42, 1329-1342.

36. Von Malmborg, F. Networking for knowledge transfer: Towards an understanding of local authority roles in regional industrial ecosystem management. Bus. Strategy Environ. 2004, 5, 334-346.

37. Tudor, T.; Adam, E; Bates, M. Drivers and limitations for the successful development and functioning of EIPs (eco-industrial parks): A literature review. Ecol. Eco. 2007, 61, 199-207.

38. Ponterosso. Available online: http://www.z-i-ponterosso.it/ (assessed on 13 July 2015).

(C) 2015 by the authors; licensee MDPI, Basel, Switzerland. This article is an open access article distributed under the terms and conditions of the Creative Commons Attribution license (http://creativecommons.org/licenses/by/4.0/). 